\title{
The Views of the Polish Political Class on the Institution of a Nationwide Referendum
}

\begin{abstract}
In the light of art. 4 of the Constitution of the Republic of Poland, the nation as a sovereign has the right to steer the state's policy, express an opinion on governing of the state, as well as co-decide with the state organs in the governing process. The nation is a source of power and may assume the role of an arbitrator in conflict situations between constitutional state organs but also in disputes between the subjects of the political scene, which is reflected in the targeting of the activities of public authorities according to the will expressed via a referendum. Due to the introduction of the principle of nation sovereignty in the Constitution of the Republic of Poland, it seemed that a nationwide referendum was bound to become an important instrument allowing the expression of opinions and formulation of decisions by the sovereign.
\end{abstract}

\section{Keywords:}

the principle of nation sovereignty, nationwide referendum, the Polish Constitutional Tribunal, the nation as a sovereign, public authorities, Polish political class, art. 4 of the Constitution of the Republic of Poland

1 Department of Constitution Law, Faculty of Law and Administration, Nicolaus Copernicus University in Toruń, Poland, zbywit@umk.pl.

2 Department of Constitution Law, Faculty of Law and Administration, Nicolaus Copernicus University in Toruń, Poland, mserowaniec@umk.pl. 
Due to the introduction of the principle of nation sovereignty in the Constitution of the Republic of Poland, it seemed that a nationwide referendum was bound to become an important instrument allowing the expression of opinions and formulation of decisions by the sovereign. In fact, as a form of participation of those governing in determining public matters, it serves the immediate expression of the political will allocated to the citizen. In the light of art. 4 of the Constitution of the Republic of Poland, the nation as a sovereign has the right to steer the state's policy, express an opinion on governing of the state, as well as co-decide with the state organs in the governing process. The nation is a source of power and may assume the role of an arbitrator in conflict situations between constitutional state organs but also in disputes between the subjects of the political scene, which is reflected in the targeting of the activities of public authorities according to the will expressed via a referendum. However, it needs to be remembered that according to the intentions of the founders of the Constitution, the direct democracy institutions should not restrict the dominant position of the parliament, hence a national referendum was attributed in the Constitution a "supplementary character" in relation to the activities of representative organs - the Sejm, and the Senate (Pietrzak, 1997, pp. 31-32). The above view was also shared by the Polish Constitutional Court in point 11.5 of judgement K11/03 as of 27 May 2003. Despite the fact that in the said judgement the CC referred to the referendum known from art. 90 sec. 3 of the Polish Constitution, its position illustrates the attitude of the Court towards any referendum regulations found in the basic law of Poland (Cf. Jabłoński, 2007, p.106, fn. 333). The Court recognised there that "the thesis on the supplementary character of direct democracy finds its justification [...] in the legal character of a referendum from the point of view of the entity entitled to refer to (initiate) the referendum procedure. In the Polish legal system, we do not speak of a civil right to a referendum, as the citizen (group of citizens) does not have a legally effective possibility to initiate actions whose immediate result consists in calling a referendum” (ibidem, p. 106). Thus, an authorised motion is the one in whose light it explicitly follows from the current Polish constitutional regulations that the institution of a referendum only seemingly has a systemic meaning, while in fact it only to a small extent constitutes the guarantee for citizens of direct participation in decision-making processes regarding matters of particular significance for the state (ibidem, p. 103).

The Polish Constitution of 2 April 1997 provides for holding a referendum in three following cases:

1) in matters of particular importance for the state (art. 125);

2) in a matter of expressing a consent to the ratification of an international agreement on whose basis Poland will transfer onto an international or- 
ganisation or an organ with the competences of a national authority certain matters (art. 90 sec. 3);

3) in a matter of an approval of a law on amending the Constitution, as far as its provisions interfere with the content of Chapter I - "Commonwealth", II - "Liberties, rights, and obligations of the man and citizen", and XII “Amendments to the Constitution” (art. 235 sec. 6).

In none of the above cases, however, there is an obligation to conduct a referendum, it is always optional and held if an authorised entity files a motion and a proper decision is taken by authorised organs.

The objective of this work is to discuss the approach of the Polish political class exclusively towards the institution of a nationwide referendum in matters of particular importance for the state. The referendum can be called by the Sejm by an absolute majority of the votes in the presence of at least half of the statutory number of members of the Sejm, or by the President of the Republic of Poland with the consent of the Senate expressed by an absolute majority of the votes in the presence of at least half of the statutory number of senators (Rachwał, 2010a, pp. 115-116, 120). At the same time, it should be noted that it is the President who determines the entire content of an ordinance to conduct a referendum, thus he decides which matters are of particular significance for the state, formulates the questions and indicates the date thereof, whereas the role of the Senate is limited to issuing a consent, i.e., passing a resolution that allows or rejects a referendum in the date and form defined by the President (Garlicki, 2001, p. 8). Moreover, a key element in the evaluation of the analysed referendum category is also an explanation of the meaning of the expression "matters of particular importance for the state”. M. Jabłoński is right to note that utilising the expression "does not constitute any model allowing for a suitable level of a priori identification of a matter to be resolved via a referendum vote. Such a solution may, on the one hand, prove the rational approach of the legislator in the sense that it is difficult to indicate a closed catalogue of such matters, thus such indefiniteness will allow for a universal reference to the existing competence, while on the other, considering the political character of the majority taking a decision on calling of a referendum, it is presumed that in many cases the assessment of the proposal to conduct the vote will be strictly political” (Jabłoński, 2007, p.104), which precludes any influence of civic character. Pursuant to art. 125 sec. 3 of the Constitution, if a national referendum is participated by more than a half of the citizens with the right of vote, the result is binding.

The conclusions that can be drawn from the current practice of the use of the institution of referendum in Poland are, however, much less optimistic. From the 
very beginning of the implementation of this institution in the Polish legal order, it was accompanied by political horse-trading. This primarily resulted from a quite sceptical attitude of the Polish political class to the institution of direct democracy, as often the members of the Constitutional Committee of the National Assembly (KKZN) voiced arguments negating the legitimacy of an immediate reference to the sovereign's will. During the Committee's deliberations, all amendments to the draft constitution that assumed introduction of the institution of obligatory referendum or proposed the option allowing for calling a referendum by the Sejm also at the initiative of at least 500 thousand citizens were rejected. Also, the amendment proposed by the two aforementioned members of the Sejm, assuming only the constitutionalisation of a motion of citizens to call a referendum, was rejected (ibidem, p. 104). Left-wing members of the Sejm challenged the importance of the institution of referendum by raising the argument that it created the premises for the establishment of "a permanent referendal republic", thus providing "a very dangerous window for numerous initiatives that would create divisions in the society and burden the state's budget”, which was seconded by some of the representatives of legal science (Cf. ibidem; KKZN, 1997, pp. 151-152). It was prophesied that instead strengthening the democratic legitimacy of a new state, a referendum would act as a convenient form of exerting constitutional pressure on the Sejm and create cycles of tensions that would destabilise the state should the motions for a referendum be rejected by the Sejm. It was feared that the subjects of referenda may be the matters of conscience or issues from the sphere of natural law (Jabłoński, 2007, p. 104). The final resolution concerning the institution of a referendum in the Constitution of 1997 clearly showed that within the member of the KKZN, and then the National Assembly passing the Constitution, the dominant conviction was that the sovereign, and thus the totality of citizens, is not only not "fully prepared for personal and direct governance" but, moreover, that the faint political culture of the sovereign means that he should not be provided by the basic law the real possibility to influence the initiation of procedures that could result in the participation in shaping of the most important state decisions that concern him (the sovereign). It was recognised that such civic participation would lead to destabilisation and threaten the state of law rather than contribute to the development of civic democracy. And this was the principal reason why a nationwide referendum was turned into a merely decorative and secondary element. It should be straightforwardly admitted that the institution of referendum was marginalised in Poland by being assigned the features of a supplemental mechanism for indirect rule or responsible government (ibidem, p. 105). Hence, although the adopted nationwide referendum mechanism in Poland 
fulfils the task of protection against its too frequent and not always justified use, at the same time it does not eliminate the risk of its entirely instrumental ad hoc use by currently ruling political majority (ibidem, p. 106). However, the worst part is that this way the Polish political class expressed its real negative view on the need to "establish citizens", the necessity to transform citizens into the actual public authority and not merely addressees and subjects/objects of its imperative actions (Dudek, 2007 p. 47). Moreover, according to the beliefs represented by the majority of politicians, the institution of referendum may only be identified with the time-consuming and costly vote of no-confidence referring to actions undertaken by democratically elected representatives. Further, they also emphasised the lack of social recognition in voting, considering the fact that each vote may turn into a sort of a survey and not a substantive determination of a crucial national matter (Jabłoński, 2002, pp. 99-118). Simultaneously, attention was paid to the fact that a referendum is not a mechanism allowing for negotiations, thus it does not create the opportunities to foster consensus capable of satisfying the demands of all the stakeholders. On the contrary, it forces opting for a particular solution, which may lead to major societal conflicts. Unfortunately, constant references to the above arguments also prove that the political class do not treat citizens as equal and full partners in the processes of governance (Jabłoński, 2001, p. 135).

Despite the fact that referenda offer the opportunity to debate and take decisions in "politically risky" matters, political parties are still not eager to run such a risk. Although in the years 1989-2015 altogether 40 motions to hold a national referendum were submitted in matters of a particular importance for the state, only in three cases were they supported by parliamentary majority. In other cases, despite submission of consecutive proposals aimed at resolving numerous significant problems, inter alia, the issue of permissibility of pregnancy termination, structure of the Polish parliament, privatisation and re-privatisation of Polish state-owned estate, enfranchisement of citizens, charges for education, territorial division of the Republic of Poland, issuing a consent to the sale of Polish land to foreigners, health care units commercialisation, or the status of the National Forests, it often became evident that politicians treated referendum as an instrument to provide the foreground to political rather than systemic and legal matters. For these reasons, despite the potential political benefits, the government elites are quite seldom interested in the utilisation of this institution.

The first referendum to be held after the year 1989 was the so-called enfranchisement referendum of 18 February 1996, which was initiated by the decree of the President of the Republic of Poland on the common enfranchisement of the citizens (Journal of Laws No 138, item 685) and the resolution of the Sejm on 
holding a referendum on some of the directions of state property use (Journal of Laws No 154, item 795) ${ }^{3}$. From the legal point of view, on 18 February 1996 two different referenda were called. However, the voter turnout was just above $32 \%$. Therefore, they proved inconsequential on account of the statutory necessity of fulfilling the turnout criterion for the validity of the referendum (over a half of those entitled to vote). The literature concludes that such a low turnout was caused mainly by the lack of a pre-referendum debate and the complexity of the questions. Secondly, the lack of a long-standing tradition of taking part in a referendum and a belief that it may have a real impact on the affairs of the state might have been attributed to its failure (Jabłoński, 2002, pp. 44-47). The latest national referendum so far took place on 6 September 2015 on the initiative of Bronisław Komorowski, the President of the Republic of Poland (Journal of Laws 2015, item 852). In a common view, this initiative, on account of the questions posed (introduction of single-mandate constituencies in parliamentary elections, the maintenance of the so-far manner of financing political parties from state budget, and the interpretation of the principles of tax law in case of doubt for the benefit of the taxpayer), was treated as an attempt to take over Paweł Kukiz' constituents and save the second ballot. However, less than three months before that time, before the referendum campaign commenced, the majority of Poles (58\%) had no awareness of what it would be about. Only 39\% of people declared to have knowledge on the issue, with only $17 \%$ being able to vouch for their knowledge (CBOS, 2015). As the commentators emphasised, presidential decision "will not increase the citizens' trust of democracy, but conversely, the citizens will distance themselves from politics, from democracy, and will not feel subjectified" (Szczęśniak, 2015). Eventually, the turnout was only 7.8\% and has been the lowest of all recorded national elections held in Europe after 1945 (Osiecki, Potocki, 2015). The referendum became a symbolic defeat of entire Polish democracy, for which politicians hold the responsibility.

As practice shows, the issues that were the subject of voting were not sufficiently recognised by a larger part of the society. From the society's point of view,

3 The citizens had four questions to answer during the referendum:

1. Are you in favour of the liabilities due to pensioners and public sector employees, arising from the decisions of the Constitutional Tribunal, to be satisfied from the privatised state assets?

2. Are you in favour of the part of privatised state assets to supply the general pension funds?

3. Are you in favour of increasing the value of participation certificates of National Investment Funds by extending the programme on other companies?

4. Are you in favour of accounting for privatisation certificates in the common enfranchisement programme? 
the referenda did not appear as procedures of direct participation in the process of exercising power but as a call for taking sides or even granting political support to a particular person or political group. A referendum, on account of the properties of human psyche, has a tendency to turn into a personal plebiscite which aims at building or denying support to a particular politician, or a group of politicians who authored the draft that has been put to vote. The draft and its properties, advantages and disadvantages are of secondary importance. As shown in practice, most frequently it becomes an act of investiture, approval or disapproval of the representatives.

A referendum has been and still is commonly treated by the political classes as an element of political struggle between particular parliamentary and extraparliamentary groups that take advantage of it for their ongoing purposes. Different political hubs attach different expectations to referenda. Some politicians treat them solely as a test of popularity of their own group. Hence, a referendum is oftentimes considered as a test for political elites, which provides more of an indication of what the current distribution of powers on the political scene is, rather than binding solutions on issues that are essential to the state. Referenda have become toys in the hands of politicians who use them as tools in electoral competition and an element of the 'power game'. The institution of the referendum has thus become another means for running their political campaign on an extended scale, which enables the gathering of numerous constituents rather than a real procedure that ensures direct exercise of power for the public (Witkowski, 2015, p. 7). It is not uncommon for the political classes to use the institution of a referendum as a tool that ensures political success for the purpose of achieving a particular electoral goal. A further point concerns taking advantage of a referendum to build a position on a political scene by the actors of political life who wish to remind the voters about their existence. This certainly does not build the authority of the institution contributing to a low turnout and its gradual devaluation.

The issue of a cryptic formulation of questions that are the subject of the referendum needs to be addressed. Regardless of their intentionality, such vague and imprecise formulation of questions obliterates the potential effect of the referendum from the start. Political parties try to convert the issue posed at the referendum into a plebiscite around particular people or political orientations that support or contest a given solution. In the experience to date, vague questions, ambiguity, insufficient, substantive and organisational preparation of the voting contribute to a low turnover in a referendum. It thus may be a priori assumed that the answers to questions formulated in such a vague manner will not lead to any accurate conclusions. Worse still, the result of such a referendum will do very little in practice, 
but it will surely become a subject of political disputes between the governing party and the opposition. In such atmosphere the citizens may be dissuaded from taking part in law-making procedures in this form. If the decision-makers assume that social engineering of that kind will help them reach their intended goals, then the referendum will not bring the desired result. If a referendum is to fulfil what is expected of it, then the questions must be formulated with the highest possible degree of precision, as only then the correct interpretation of its results will be possible. Otherwise, it is possible to imagine a situation in which a referendum turns into a plebiscite of popularity and resentment, and not a way of making binding decisions (Jabłoński, 2003, pp. 16-17).

The political class loses campaigns for referenda with a systematic precision. The entities that take part in them should demonstrate and explain to the public the benefits and dangers of the proposed solutions. However, political parties in our country are unable to present the advantages of the proposed solutions to an average citizen. Political powers in this country treat referendum campaigns not as debates about pivotal issue for the state, but as a way of building electorate and mustering up the voters. The studies also show that campaigns that propagate the referendum in mass media have been delivered to the public in a limited manner. It is far from being optimistic to realise that the campaigns prior to the referenda have been a display of demagogy rather than a substantial and factual debate with arguments (Rachwał, 2010b, pp. 89-90). A referendum has thus become "a tasty morsel" for politicians in their fight to strengthen the position of their parties rather than educate the voters. However, what is even more surprising, the referendum-holding authority, as seen in previous cases, refrains from running an extensive referendum campaign and utilising the dedicated transmission time. In such a situation, the subject of the referendum becomes less important as the main goal of the participation in the referendum campaign is the emphasis of one's own political independence and distinctness. It should come as no surprise that the information campaigns held to date have been shallow in terms of substance, chaotic and focused on political competition. An obvious underlying political context, badly prepared questions and the lack of a real referendum campaign held in the media and the largest parties, translates into a very low turnout. Thus, the voters' indifference as regards the possibility to make decisions about the affairs of the state comes as no surprise. They have lost a sense of any real impact on the actions of the authorities as they have no guarantees that, regardless of the governing political elites, they will make decisions on the affairs that are essential to the state and, most importantly, for themselves (Jabłoński, 1997, p. 84). 
The practice of applying a national referendum in Poland has not allowed to fully exploit the opportunities that direct democracy brings to the process of constructing a civil society. A general reflection on the lost opportunities in terms of the functioning of political institutions due to insufficient professionalism both in the process of shaping appropriate legal measures as well as applying them in practice, remains. In order for a referendum to be able to fulfil its basic functions, certain requirements need to be met. Firstly, the issues that are to be regulated must be clearly and precisely formulated. It must also be preceded by a sufficiently long and thorough campaign, in which the society will have a chance to be confronted with different standpoints. This way it becomes subjectified and at the same time the possibility of any manipulations that political parties may be tempted to effect is diminished. Last but not least, the institution of the referendum may serve its purpose if it is acclaimed by the society and is welcomed by the political forces which strive to integrate democratic procedures into solving the crucial issues of social, political and systemic life (Jabłoński, 1997).

\section{References:}

CBOS survey message No 89/2015 Referendum - first reactions before the commencement of the campaign. Retrieved from: http://www.cbos.pl/SPISKOM.POL/2015/K_089_15. PDF.

Dudek, D. (2007). Konstytucyjna aksjologia wyborów [Constitutional axiology of elections]. In: F. Rymarz, Iudices electionis custodes (sędziowie kustoszami wyborów), Warszawa: Wydawnictwo Krajowego Biura Wyborczego, 47.

Garlicki, L. (2001). Komentarz do art. 125 Konstytucji [A commentary to art. 125 of the Constitution]. In: L. Garlicki (ed.), Konstytucja Rzeczypospolitej Polskiej. Komentarz. Warszawa: Wydawnictwo Sejmowe.

Jabłoński, M. (1997). Referendum de lege lata i de lege ferenda. Acta Universitatis Wratislaviensis. Przegląd Prawa i Administracji, 39, 75-84.

Jabłoński, M. (2001). Referendum ogólnokrajowe w polskim prawie konstytucyjnym [National referendum in the Polish constitutional law]. Wrocław: Wydawnictwo Uniwersytetu Wrocławskiego.

Jabłoński, M. (2002). Referendum ogólnokrajowe w pracach Komisji Konstytucyjnej Zgromadzenia Narodowego (1993-1997) [National referendum in the works of the Constitutional Committee of the National Assembly (1993-1997)]. Acta Universitatis Wratislaviensis. Przegląd Prawa i Administracji, 49, 99-118.

Jabłoński, M. (2003). Referendum ogólnokrajowe. Wybrane zagadnienia [National referendum. Selected issues]. Palestra, (5-6), 16-17.

Jabłoński, M. (2007). Polskie referendum akcesyjne [Polish accession referendum]. Wrocław: Wydawnictwo Uniwersytetu Wrocławskiego.

KKZN (1997). Biuletyn, XLIV. Warszawa: Wydawnictwo Sejmowe. 
Osiecki, G., Potocki, M. (2015). Referendum przeszło do historii [Referendum went down in history]. Dziennik Gazeta Prawna, 8 September 2015.

Pietrzak, M. (1997). Demokracja reprezentacyjna i bezpośrednia w Konstytucji RP [Representative and direct democracy in the Polish Constitution]. In: M.T. Staszewski (ed.), Referendum konstytucyjne w Polsce [Constitutional referendum in Poland]. Warszawa: ISP PAN, 31-32.

Rachwał, M. (2010a). Prawo do zarządzania referendum ogólnokrajowego w Polsce w latach 1992-2009. Przyjęte rozwiązania i postulowane zmiany [The right to call a national referendum in Poland in the years 1992-2009. The adopted solutions and postulated changes]. In: A. Stelmach (ed.), Prawo wyborcze i wybory. Doświadczenia dwudziestu lat procesów demokratyzacyjnych $w$ Polsce [The right of vote and the election. The experience gained in the twenty years of democratisation processes in Poland] (p. 115-126). Poznań: Wydawnictwo Naukowe WNPiD UAM.

Rachwał, M. (2010b). Demokracja bezpośrednia w procesie kształtowania społeczeństwa obywatelskiego $w$ Polsce [Direct democracy in the process of shaping the civil society in Poland]. Warszawa: Wydawnictwo Sejmowe.

Szczęśniak, A. (2015). Referenda became a toy in the hands of politicians. Retrieved from: http://wiadomosci.onet.pl/szczesniak-referenda-staly-sie-zabawka-w-rekachpolitykow/kvs33q.

The Decision of the President of the republic of Poland of 17 June 2015 on calling a national referendum (Journal of Laws 2015, item 852).

The Decree of the President of the Republic of Poland of 21 December 1995 on holding a referendum concerning some of the directions of state property use (Journal of Laws No 154, item 795).

The Decree of the President of the Republic of Poland of 29 November 1995 on holding a referendum concerning the common enfranchisement (Journal of Laws No 138, item 685).

Witkowski, Z. (2015). Siedem grzechów głównych polskiej klasy politycznej wobec wyborców, wyborów i prawa wyborczego [Seven cardinal sins of the Polish political class in relation to their voters and the election law]. Toruń: TNOiK „Dom Organizatora”. 